\title{
EFFECT OF ORGANIC WASTE CONCENTRATION ON REACTOR PERFORMANCE IN ANAEROBIC CO-FERMENTATION OF WASTEWATER OF TOFU INDUSTRY AND ORGANIC SOLID WASTE
}

\author{
Pengaruh Konsentrasi Sampah Organik terhadap Kinerja Reaktor pada \\ Ko-Fermentasi Anaerobik Limbah Cair Industri Tahu dan Sampah Organik
}

\author{
Sofyan* and Salmariza, Sy \\ Institution of Research and Standardization of Industry \\ Jl. Raya LIK No. 23 Ulu Gadut Padang 25164 \\ *e-mail: sofyan@kemenperin.go.id
}

Diterima: 27 Februari 2015, revisi akhir: 18 Mei 2015 dan disetujui untuk diterbitkan: 12 Juni 2015

\begin{abstract}
Fuel crisis of oil and gas that are faced currently requires a thought to look for an alternative energy. The objective of this study was to observe the effect of organic waste addition on reactor performance and to increase the production of biogas as an alternative renewable energy. The wastewater used was the wastewater from agglomeration of soy pulp in tofu industry, while the solid waste used was a mixture of organic waste from household and market waste. The study was conducted by fermenting the wastewater and organic waste together with sample volume $300 \mathrm{ml}$. The reactors were operated semi-continuously with substrate feeding every two weeks. The treatment used in this study were mass comparison of organic waste and wastewater (0:100)\%; (5:95)\%; (10:90)\%; (20:80)\%; (30:70)\%; and (40:60)\%. The results showed that the addition of organic waste affected the reactor performance and the amount of biogas produced. Anaerobic co-fermentation of wastewater from tofu industry and organic waste produced biogas more than fermentation of wastewater without organic waste. The highest amount of biogas was obtained in the treatment of organic waste addition as much as $30 \%$ with average volume of biogas was $728 \mathrm{ml}$ in steady state condition.
\end{abstract}

Keywords: Organic waste, wastewater, tofu industry, anaerobic, co-fermentation

\section{ABSTRAK}

Krisis bahan bakar minyak dan gas yang dihadapi saat ini memerlukan pemikiran untuk mencari energi alternatif. Penelitian ini bertujuan untuk mengamati pengaruh penambahan sampah organik terhadap kinerja reaktor anaerobik dan meningkatkan produksi biogas sebagai salah satu energi alternatif terbarukan. Limbah cair yang digunakan adalah limbah cair dari penggumpalan bubur kedelai pada industri tahu, sedangkan sampah organik yang digunakan adalah gabungan sampah organik dari rumah tangga dan sampah pasar. Penelitian dilakukan dengan mendigestasi limbah cair industri tahu dan sampah organik secara bersama-sama dalam reaktor anaerobik dengan volume sampel $300 \mathrm{ml}$. Reaktor dioperasikan secara semi kontinyu dengan pengumpanan substrat setiap dua minggu sekali. Perlakuan yang dilakukan adalah perbandingan massa sampah organik dan limbah cair yaitu (0:100)\%; (5:95)\%; (10:90)\%; (20:80)\%; (30:70)\%; dan (40:60)\%. Hasil penelitian menunjukkan bahwa penambahan sampah organik mempengaruhi kinerja reaktor dan jumlah biogas yang dihasilkan. Fermentasi anaerobik limbah cair industri tahu dan sampah organik menghasilkan biogas lebih banyak dibandingkan dengan fermentasi limbah cair industri tahu tanpa sampah organik. Jumlah biogas terbanyak diperoleh pada perlakuan penambahan sampah organik $30 \%$ dengan volume biogas rata-rata $728 \mathrm{ml}$ pada kondisi tunak.

Kata Kunci: Sampah organik, limbah cair, industri tahu, anaerobik, ko-fermentasi 


\section{INTRODUCTION}

Tofu industry is one of the industries which produce a lot of liquid waste in its production process. The generated liquid waste can be derived from variety of sources, started from washing process until agglomeration process of soybeans pulp become tofu. There are only a little of tofu industry in general that implement the treatment of liquid waste which can pollute the environment. High organic content in the wastewater of tofu industry require appropriate handling in its processing so that the liquid waste discharged into public waters to be safe for the environment.

On the other hand, organic waste from households as food waste is also a problem for the environment. The untreated food waste is known to cause many environmental problems, such as contaminations of soil, water, and air during collection, transportation and storage due to its rapid decomposition (Han \& Shin, 2004). Currently, various methods for reutilization and disposal of the food waste are available, which include landfill, incineration, use of animal feed, aerobic composting and anaerobic digestion. Due to newly issued environmental regulations, some disposal methods are going to be prohibited and becoming less desirable (Kelley \& Walker, 2000: Oh et al., 2008).

According to Bahrin et al., (2011), for each type of organic material consisting of carbohydrates, proteins, and fats compound can be processed in order to obtain biogas. However, anaerobic bacteria can not live with heterogeneous organic waste, in order to produce biogas the organic waste needs further processing to be used as raw material.

The energy crisis is happening today is characterized by the increasing price of fuel oil and gas that will make industry pay a high operational costs for fuel. This certainly will burden the industry, both small and medium industries and large industries. Therefore, it should be considered the utilization efforts of cheap alternative energy sources and environmental friendly.

Based on the problems, needs to be considered the management efforts so that the environment is keep maintained. One of the solutions that can be done is by bioprocess technology, which of the process will produce biogas that can be used as an energy source. The utilization of wastewater from tofu industry and organic waste from households and markets as a source of energy is a way that can be done to solve the problems.

Various techniques for treatment of wastewater have been developed. One of the methods that can be applied is anaerobic fermentation. Anaerobic digestion technology is commonly suggested as one of the most sustainable options to stabilize tremendous amount of organic fraction municipal solid waste ( $\mathrm{Ge}$ et al., 2010) because this technology recovers methane $\left(\mathrm{CH}_{4}\right)$ gas, which can be utilized as a renewable bioenergy (Lv et al., 2010). Wang et al., (2005) also reported that nowadays, anaerobic digestion of the food waste is attracting strong interest, and many novel anaerobic digestion systems have been developed and applied to treat the food waste. Two-stage anaerobic digestion system and HASL (hybrid anaerobic solid-liquid) system are well known examples (Wang et al., 2005).

Anaerobic fermentation to get biogas is bioprocess technology that involves the function of microorganisms in the process. Many factors determine the success and effectiveness. Utilization of wastewater from tofu industry to biogas has been done a lot, however fermentation of the wastewater alone sometimes often less effective and takes a long time in the process. Similarly, the fermentation of organic waste alone will not provide optimal results. This is caused by a lack of nutrients necessary for the sustainability of anaerobic processes in the wastewater.

Nowadays, anaerobic co-fermentation has attracted more attentions (Angelidaki and Ellegaard, 2003; Creamer et al., 2010; Heo et al., 2003). Many studies about cofermentation had been reported. A study about co-fermentation of wastewater from tofu industry and organic waste was reported by Sofyan et al., (2012). Sofyan et al., (2012) reported that composition of organic waste would affect reactor condition and amount of biogas produced. The highest number of 
biogas was obtained at waste composition ratio of rice and vegetables $(20: 80) \%$.

Co-fermentation with high organic contents such as food waste could be a reliable option to enhance activity of anaerobic microorganisms. Proper mixture brings synergistic and complementary effects, which offset the lack of carbon sources in sewage sludge and dilute harmful or excessive substances inhibiting anaerobes in food waste (Kim et al., 2007).

According to Wikan et al., (2009), rapid population growth and development of industrial sector can lead to increase energy demand and decrease environmental quality. Indonesia is one of the countries producing oil and gas, declining oil reserves and cancellation oil subsidies can increase oil prices and environmental degradation due to the use of excessive fossil fuel. Utilization of renewable energy is required because it can be one of the alternative sources of energy that are environmental friendly. Biogas is a renewable energy that has a very promising prospect for development.

According to Scholz \& Ellner (2011), biogas is suitable to be used due to the high percentage of Hydrogen and very easy to produce, moreover the emission is not harmful so it should be considered for large scale applications.

According to Salomon (2009) in Arthur, Baidoo \& Antwi (2011), the use of biogas from municipal waste not only as one of the solutions to the problem of energy crisis but also can improve the environment through proper waste management, conservation of ground water and surface water, create jobs, reduce poverty, and create sustainable development.

The objective of this study was to see the effect of organic waste addition on anaerobic reactor performance and to increase the production of biogas. Organic waste contains nutrients necessary to improve the effectiveness of the anaerobic process. By combining these two materials in a process is an alternative that expected to improve the effectiveness of the anaerobic process which is marked by an increased amount of biogas produced. Many studies showed that the sensitivity of the anaerobic digestion process to the environmental changes may be improved by combining several waste streams (Creamer et al., 2010; Heo et al., 2003).

\section{RESEARCH METHODS}

The wastewater used for this experiment was taken from tofu industry. It was the residual wastewater from agglomeration of soy pulp taken from a tofu industry in Padang City. The solid waste used was organic waste taken from households and from Bandar Buat Market in Padang City. Other materials used were chemicals for analysis of COD, BOD, total solid, total nitrogen, total ammonia, and $\mathrm{pH}$.

The equipment used were the anaerobic digestion bottles, BOD incubator, $\mathrm{pH}$ meter, equipment for the analysis of COD (COD reactor, spectrophotometer, COD tube), equipment for analysis of total a m monia and total nitrogen (spectrophotometer, autoclave, refining sample equipment), and equipment for analysis of total solids (oven, desiccators, analytical balance). Analytical methods of COD, BOD, total solid, total Ammonia, total Nitrogen, and $\mathrm{pH}$ refered to the SNI SNI 6989.73:2009, SNI 6989.72:2009, SNI 066989.26-2005, SNI 06-6989.30-2005, SNI 06-6989.52-2005, SNI 06-6989.11-2004 respectively.

The study was conducted by digesting the wastewater and organic waste together by varying the concentration of organic waste. The organic waste was a fixed variable with composition (weight percentage) of rice waste from household $(20 \%)$, fish waste from households (5\%), and vegetable waste from Bandar Buat Market in Padang City (75\%). The treatment study was conducted as in Table 1.

Starter was made by mixing cow manure and water with a concentration of $30 \%$ as much as $270 \mathrm{ml}$, then added wastewater from tofu industry as much as 30 $\mathrm{ml}$. Starter was incubated at $36^{\circ} \mathrm{C}$ until it was produced biogas and $\mathrm{pH}$ value in accordance with the conditions of anaerobic process. The study was conducted using $500 \mathrm{ml}$ glass bottles as anaerobic reactors and operated semi-continuously with substrate feeding every two weeks. The total 
material volume digested was $300 \mathrm{ml}$. The operational steps of the study was as following points.

Table 1. Treatment of the study

\begin{tabular}{ccc}
\hline $\begin{array}{c}\text { Treat- } \\
\text { ment }\end{array}$ & $\begin{array}{c}\text { Organic waste } \\
\text { percentage (\%) }\end{array}$ & $\begin{array}{c}\text { Wastewater } \\
\text { percentage (\%) }\end{array}$ \\
\hline A & 0 & 100 \\
\hline B & 5 & 95 \\
\hline C & 10 & 90 \\
\hline D & 20 & 80 \\
\hline E & 30 & 70 \\
\hline F & 40 & 60 \\
\hline
\end{tabular}

Starter which had been cultured was taken as much as $270 \mathrm{ml}$ and then put into the reactor. The mixture of wastewater and organic waste as substrate was taken $30 \mathrm{ml}$ for substrate addition rate of $2.14 \mathrm{ml} / \mathrm{day}$, then put into the reactor which contained the starter. The reactor was closed and put into an incubator at a temperature $36^{\circ} \mathrm{C}$.

After two weeks, the gas produced was measured, and then withdrawn $30 \mathrm{ml}$ of solution from the reactor and filled a new 30 $\mathrm{ml}$ substrate. The reactor which had been added a new substrate, then was closed and put back into the incubator. The sample that was taken from the reactor, then analyzed the $\mathrm{pH}, \mathrm{COD}, \mathrm{BOD}$, sulfide, total nitrogen, total ammonia, and total solid. The steps were conducted until a steady state condition.

\section{RESULT AND DISCUSSION Characteristics of Substrate and Starter}

The starter which was used in the study had the characteristics as in Table 2, while the mixture of tofu industry wastewater and organic waste used as a substrate had the characteristics as shown in Table 3. From Table 3 can be seen that the addition of organic waste into wastewater would increased organic loading of the substrate.

Substrate A that was a wastewater alone without addition of organic waste was a control substrate and used for comparison had the lowest organic contaminant load compared to other substrates. Substrate $F$ with the percentage of organic waste $40 \%$ had the highest organic contaminant load with the COD value $52300 \mathrm{mg} / \mathrm{l}$.

Table 2. Characteristics of starter

\begin{tabular}{|c|c|c|c|}
\hline No. & Parameter & Unit & Result \\
\hline 1 & $\mathrm{pH}$ & - & 6.64 \\
\hline 2 & BOD-5 & $\mathrm{mg} / \mathrm{L}$ & 2712 \\
\hline 3 & COD & $\mathrm{mg} / \mathrm{L}$ & 12600 \\
\hline 4 & Volume of Biogas & $\mathrm{mL}$ & 549 \\
\hline
\end{tabular}

Tabel 3. Characteristics of substrate

\begin{tabular}{ccccccccc}
\hline \multirow{2}{*}{ No. } & \multirow{2}{*}{ Parameter } & \multirow{2}{*}{ Unit } & \multicolumn{7}{c}{ Result } \\
\cline { 4 - 9 } & & & $\mathrm{A}$ & $\mathrm{B}$ & $\mathrm{C}$ & $\mathrm{D}$ & $\mathrm{E}$ & $\mathrm{F}$ \\
\hline 1 & $\mathrm{pH}$ & - & 6.77 & 6.86 & 6.80 & 6.66 & 6.65 & 6.73 \\
\hline 2 & $\mathrm{BOD}-5$ & $\mathrm{mg} / \mathrm{L}$ & 2369 & 14528 & 17266 & 19477 & 22623 & 25417 \\
\hline 3 & $\mathrm{COD}$ & $\mathrm{mg} / \mathrm{L}$ & 9350 & 26100 & 30300 & 34500 & 40100 & 52300 \\
\hline 4 & Sulfide & $\mathrm{mg} / \mathrm{L}$ & 2.71 & 0.16 & 0.34 & 0.41 & 0.42 & 0.72 \\
\hline 5 & Total Nitrogen & $\mathrm{mg} / \mathrm{L}$ & 676 & 1045 & 1308 & 1597 & 1884 & 1885 \\
\hline 6 & Total Solid & $\mathrm{mg} / \mathrm{L}$ & 19888 & 24548 & 27640 & 33792 & 52072 & 59460 \\
\hline 7 & Total Carbon & $\mathrm{mg} / \mathrm{L}$ & 14448 & 18064 & 21864 & 25988 & 40344 & 48008 \\
\hline 8 & Total Ash & $\mathrm{mg} / \mathrm{L}$ & 3868 & 3952 & 4132 & 4748 & 4820 & 5928 \\
\hline
\end{tabular}

Substrates contained high enough carbon characterized by high values of $B O D$ and COD. Carbon is one of the necessary matterial in the anaerobic fermentation. According to Raheman \& Mondal (2012), in addition to a role in the formation of cytoplasmic conducted by microorganisms, Carbon also play a role in the formation of energy for microorganism's activity. If the available excess Carbon, Nitrogen will be 
consumed faster and decomposition of organic matter will be reduced. The imbalance ratio of $\mathrm{C} / \mathrm{N}$ will affect the microbial activity and the resulting gas.

Raheman et al., (2012) reported that the advantages of total Nitrogen in the substrate as an essential element used for synthesis of amino acids, proteins, and nucleic acids. In addition the Nitrogen is converted into ammonia, a strong base, and a neutralizing acid which is volatile by bacteria and the presence of Nitrogen as a regulator of conditions at neutral $\mathrm{pH}$ is very important to the growth of cells.

\section{Observations of Reactor Performance Production of biogas}

Observational data of biogas volume for 18 weeks of observation time can be seen in Figure 1. From the observation, the treatment $E$ with composition of $30 \%$ organic waste and $70 \%$ wasteweater produced the highest biogas with biogas volume at week $18^{\text {th }}$ as much as $720 \mathrm{ml}$. This was twice than biogas in fermentation of wastewater alone. All treatments were in good condition up to week $18^{\text {th }}$ except treatment $F$ with substrate composition $40 \%$ organic waste and $60 \%$ wastewater.

When compared to treatment $A$ (substrate without organic waste), the treatment using a substrate with a mixture of waste produced biogas more, except for treatment $F$. This was because the substrate containing waste will provide a balance of nutrients in the anaerobic process so that will produce more biogas. The addition of organic waste as a substrate however must also consider the pollution load and seek for an appropriate residence time for each different substrate.

This result is consistent with study conducted by Zhang et al. Zhang et al., (2013) reported the production of biogas increased significantly during the codigestion process when compared with the normal process. Taken together, these improvements indicated that optimization of the sludge composition by mixing it with kitchen garbage has the potential for use in anaerobic digestion of nutrient-deficient sludge. Nayono et al., (2009) observed that with food waste as co-substrate, an increase of $21-37 \%$ in biogas production compared to the periods with only biowaste as substrate.

Treatment $F$ produced the highest biogas at the beginning of the process, but it dropped dramatically at week $8^{\text {th }}$ accompanied by a decrease in $\mathrm{pH}$. During the process, treatment $F$ run less stable, after week $8^{\text {th }}$, the biogas production started to climb up to week $12^{\text {th }}$, but then it continued to fall until only $140 \mathrm{ml}$ at week $18^{\text {th }}$, the lowest biogas volume compared to other treatments. This was because this treatment had a very high pollution load of the substrate so that it took a longer time to decompose organic compounds that existed compared to other treatments. The average amount of biogas of all treatments in steady state condition is shown Table 4.

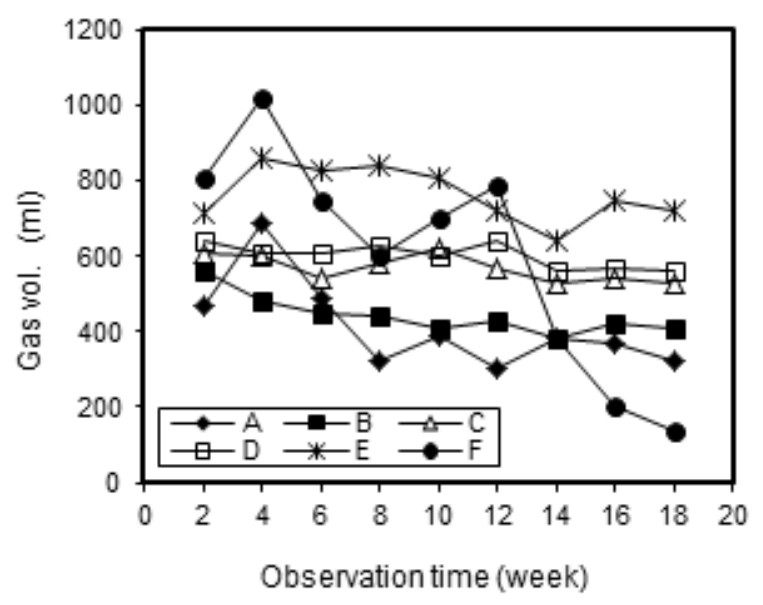

Figure 1. Biogas volume observation

Table 4. Average amount of biogas

\begin{tabular}{ccc}
\hline No. & Treatment & Gas volume $(\mathrm{ml})$ \\
\hline 1 & $\mathrm{~A}$ & 353 \\
\hline 2 & $\mathrm{~B}$ & 410 \\
\hline 3 & $\mathrm{C}$ & 558 \\
\hline 4 & $\mathrm{D}$ & 586 \\
\hline 5 & $\mathrm{E}$ & 728 \\
\hline 6 & $\mathrm{~F}$ & $\begin{array}{r}\text { Uncounted because } \\
\text { unstable }\end{array}$ \\
\hline
\end{tabular}

Methane gas was not analyzed in this study, Ward et al., (2008) reported that biogas is generally composed of $48-65 \%$ methane, $36-41 \%$ carbon dioxide, up to $17 \%$ nitrogen, <1\% oxygen, 32-169 ppm hydrogen sulphide and traces of other gases. According to Martin-Gonzalez et al., 
(2010), co-digestion resulted in an increase of $72 \%$ in biogas production and $46 \%$ methane yield in comparison with municipal solid waste. According to Wikan et al., (2009), the production of methane gas is influenced by the $\mathrm{C} / \mathrm{N}$ ratio, retention time, $\mathrm{pH}$, temperature, and toxicity of cow manure used. Omar et al., (2007) in Bahrin et al., (2011) also reported that the advantage garbage vegetables used in the production of biogas from municipal waste is not required the addition of nutrient because of nitrogen content in a large number.

\section{pHobservation}

Observation of $\mathrm{pH}$ of the solution at each reactor is presented in Figure 2, while the average of $\mathrm{pH}$ value can be seen in Table 5. Treatment $A$ to $E$ had a pH that was at neutral condition between 6.65 and 7.11 up to week $18^{\text {th }}$. This was an indication that the anaerobic process in reactors run pretty well.

After fermentation the $\mathrm{pH}$ di not change too far when compared to initial pH except for treatment $\mathrm{F}$. Range $\mathrm{pH}$ obtained was almost similar to the study reported by Budiyono et al., (2010). Budiyono et al., (2010) reported that prior to fermentation $\mathrm{pH}$ range from 6.37 to 6.62 while after fermentation between 6.70 and 6.97. The increase of $\mathrm{pH}$ value estimated because the degradation of proteins became ammonia.

Table 5. $\mathrm{pH}$ average value

\begin{tabular}{ccc}
\hline No. & Treatment & $\mathrm{pH}$ \\
\hline 1 & $\mathrm{~A}$ & 6.83 \\
\hline 2 & $\mathrm{~B}$ & 6.93 \\
\hline 3 & $\mathrm{C}$ & 6.88 \\
\hline 4 & $\mathrm{D}$ & 6.67 \\
\hline 5 & $\mathrm{E}$ & 6.53 \\
\hline 6 & $\mathrm{~F}$ & $\begin{array}{c}\text { Uncounted because } \\
\text { unstable }\end{array}$ \\
\hline
\end{tabular}

Treatment $\mathrm{F}$ had a neutral $\mathrm{pH}$ at the beginning of the process up to the $10^{\text {th }}$ week, but after that it kept to fall until 4.91 at the $18^{\text {th }}$ week. This was an indication of the failure of anaerobic process in reactor $F$. This could be caused by the high of organic waste in this substrate. This result was appropriate with the results reported by Gamayanti et al.,
(2012). According to Gamayanti et al., (2012), the excess substrate was fed into the digester will lead to more active and more rapid af acidogen and acetogen bacterial growth so that organic matter (carbohydrates, proteins, and fats) will be converted more into fatty acids. This was the cause of the $\mathrm{pH}$ drop. At low $\mathrm{pH}$, methanogenic bacteria could not work optimally so that would be the imbalance be t ween acidogenes is and methanogenesis.



Figure 2. pHobservation in reactor

Acidic condition in the reactor $F$ was caused by the high content of volatile acids such as propionic and butyric acids are usually formed in the asetogenic process. In normal anaerobic condition, these acids will be decomposed further into methane gas. In reactor $F$, the formed acids did not decompose yet into methane gas that affected the $\mathrm{pH}$ of the solution and the formed methane gas. Because of its high pollution load, this treatment required a longer time to decompose the formed acids in the acetogenic process.

\section{COD and BOD observation}

Observations of COD and BOD values in each reactor is shown in Figure 3 and Figure 4, while the COD and BOD average at steady state condition and $\mathrm{COD}$ and $\mathrm{BOD}$ reduction against substrates presented in Table 6.

The average value was taken from the last two weeks data. The percentage of COD 
reduction ranged from $30.1 \%$ to $55.6 \%$. Treatment $A$ (control) had the smallest reduction percentage than other treatments with an average COD concentration 6535 $\mathrm{mg} / \mathrm{L}$.

It showed that only a small fraction of organic matter was decomposed and formed into biogas. Another possibility was because the COD concentration of starter bigger than the COD concentration of the substrate. It also happened in BOD observation, where treatment $A$ had the smallest reduction percentage $23.5 \%$.

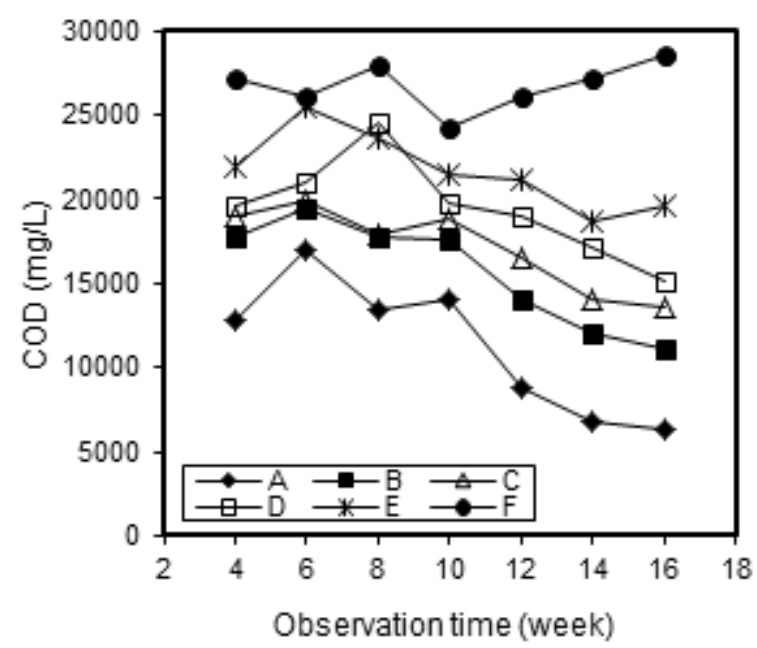

Figure 3. Observation of COD

Among treatment using organic waste, treatment $B$ had the highest reduction percentage of COD and BOD compared to other treatments, namely $55.6 \%$ and $78.6 \%$.
This was because the substrate B had the smallest contaminant loads than other substrates that using organic waste. Instead substrate $F$ had the smallest reduction percentage of COD and BOD, namely $46.8 \%$ and $50.7 \%$. This was due to the unfavorable conditions and high substrates load so that it took longer to degrade the available organic matter.

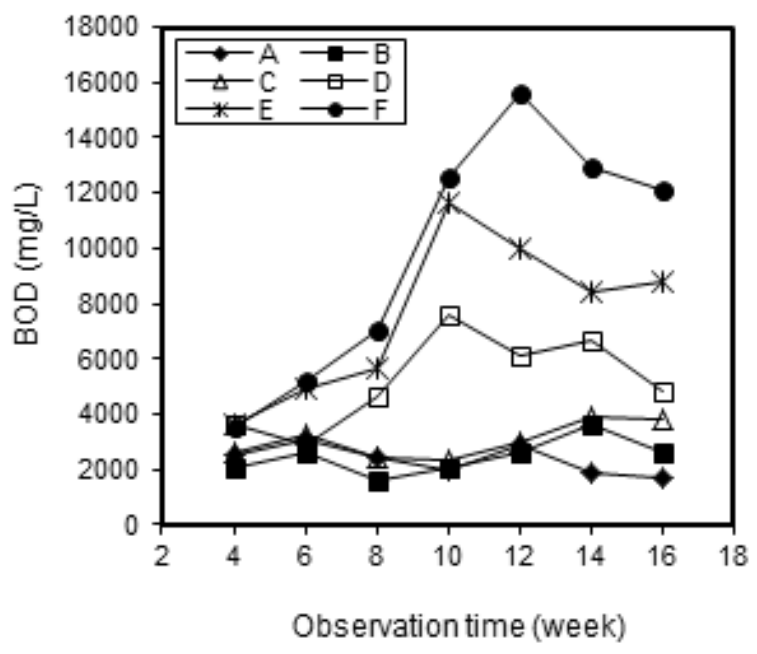

Figure 4. Observation of BOD

Range of COD percentage reduction in this study was almost similar to research conducted by Dhadse et al., (2010). Dhadse et al., (2010) reported that the study had average COD influent $28300 \mathrm{mg} / \mathrm{L}$, while the average BOD $8512 \mathrm{mg} / \mathrm{L}$. The average reduction of COD and BOD in the study were $64.86 \%$ and $65.47 \%$ respectively .

Table 6. Average of COD and BOD in steady state condition

\begin{tabular}{cccccc}
\hline No. & Treatment & $\begin{array}{c}\text { Average COD } \\
(\mathrm{mg} / \mathrm{l})\end{array}$ & $\begin{array}{c}\text { COD reduction } \\
(\%)\end{array}$ & $\begin{array}{c}\text { Average } \\
\text { BOD }(\mathrm{mg} / \mathrm{l})\end{array}$ & $\begin{array}{c}\text { BOD reduction } \\
(\%)\end{array}$ \\
\hline 1 & $\mathrm{~A}$ & 6535 & 30.1 & 1812 & 23.5 \\
\hline 2 & $\mathrm{~B}$ & 11590 & 55.6 & 3105 & 78.6 \\
\hline 3 & $\mathrm{C}$ & 13775 & 54.5 & 3871 & 77.6 \\
\hline 4 & $\mathrm{D}$ & 16120 & 53.3 & 5779 & 70.3 \\
\hline 5 & $\mathrm{E}$ & 19075 & 52.4 & 8590 & 62.0 \\
\hline 6 & $\mathrm{~F}$ & 27825 & 46.8 & 12528 & 50.7 \\
\hline
\end{tabular}

\section{Total solid observation}

Observation data of total solids (TS) in each reactor is presented in Figure 5, while the average TS and TS percentage reduction against the substrate concentration is shown in Table 7. TS concentration tended to fall on each treatment. This was because the 
concentration of TS starter was very low compared to concentration of TS substrate.

If compared to overall treatment that did not use organic waste substrate (control) and substrate that used waste treatment, the smallest percentage reduction of TS was control treatment. Although condition of treatment $F$ was not good enough, but the highest of percentage decrease of TS in this treatment was $67.2 \%$. This indicated that in the reactor still occurring organic matter degradation activities was characterized with lower TS concentration in the solution.

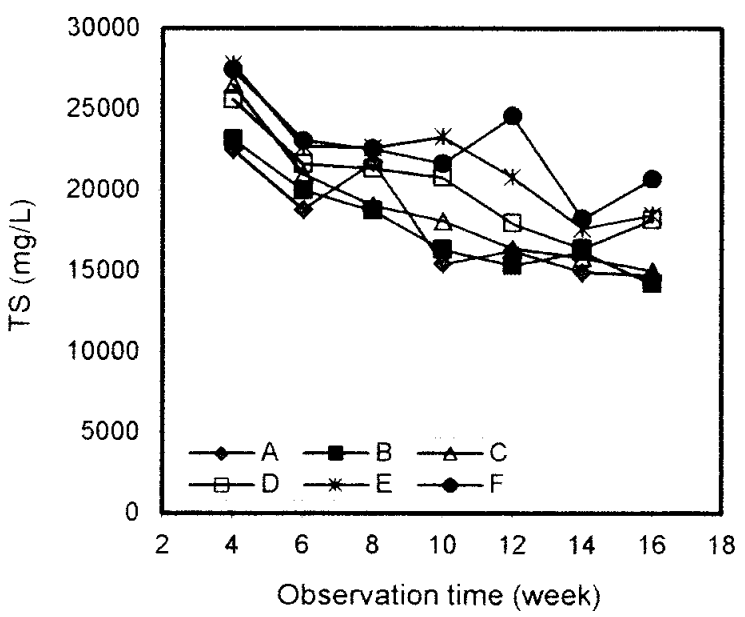

Figure 5. TS observation

Table 7. TS average in steady state condition

\begin{tabular}{cccc}
\hline No. & $\begin{array}{c}\text { Treat- } \\
\text { ment }\end{array}$ & $\begin{array}{c}\text { TS average } \\
(\mathrm{mg} / \mathrm{l})\end{array}$ & $\begin{array}{c}\text { TS reduction } \\
(\%)\end{array}$ \\
\hline 1 & $\mathrm{~A}$ & 14850 & 25.3 \\
\hline 2 & $\mathrm{~B}$ & 15230 & 38.0 \\
\hline 3 & $\mathrm{C}$ & 15450 & 44.1 \\
\hline 4 & $\mathrm{D}$ & 17305 & 48.8 \\
\hline 5 & $\mathrm{E}$ & 18070 & 65.3 \\
\hline 6 & $\mathrm{~F}$ & 19490 & 67.2 \\
\hline
\end{tabular}

Total solid content of the substrate affected the anaerobic reactor performance. This was in line with research conducted by Fernandez et al., (2008). It was reported that the initial concentration and total solid content of the substrate in the bioreactor can significantly affect the performance of the process and the amount of methane produced during the process (Fernandez et al., 2008).

\section{Total Nitrogen observation}

Observation of Total Nitrogen (TN) in each reactor is presented in Figure 6 and the percentage of reduction is shown in Table 8. Concentration of Nitrogen in treatment A, B, and $C$ was constant since the beginning of the process till the $16^{\text {th }}$ week. Decrease of Nitrogen concentration of substrate occured in all treatments overall with a different of decrease concentration. It showed that Nitrogen compounds were decomposed by anaerobic activity.

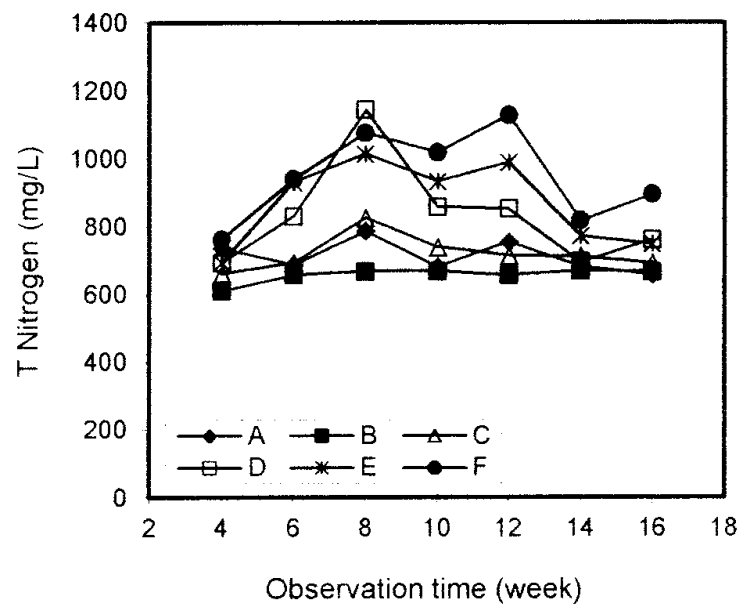

Figure 6. Total Nitrogen observation

Table 8. Total Nitrogen average in steady state condition

\begin{tabular}{cccc}
\hline No. & Treatmen & $\begin{array}{c}\text { TN average } \\
(\mathrm{mg} / \mathrm{l})\end{array}$ & $\begin{array}{c}\text { TN reduction } \\
(\%)\end{array}$ \\
\hline 1 & $\mathrm{~A}$ & 671 & 0.8 \\
\hline 2 & $\mathrm{~B}$ & 669 & 36.0 \\
\hline 3 & $\mathrm{C}$ & 703 & 40.7 \\
\hline 4 & $\mathrm{D}$ & 730 & 44.2 \\
\hline 5 & $\mathrm{E}$ & 761 & 52.4 \\
\hline 6 & $\mathrm{~F}$ & 858 & 54.5 \\
\hline
\end{tabular}

Excess nitrogen in the substrate can lead to the formation of ammonia in quantities large enough so that the results obtained are toxicity. It should be consider that the content of Nitrogen in the substrate in order to know the content of nutrients (Raheman et al., 2012). In the organic fraction of household organic waste, Nitrogen content is released in the form of 
ammonia during anaerobic fermentation process in the amount of $2.15 \mathrm{~g} \mathrm{~N} / \mathrm{L}$ Vindis et al., (2009).

\section{CONCLUSIONS}

This study showed that organic waste could be digested together with wastewater from tofu industry and produced biogas. The addition of organic waste in anaerobic digestion would increase the biogas produced, which the amount would depend on the concentration of the added waste. The average of biogas amount in anaerobic digestion of wastewater alone was $353 \mathrm{ml}$ every two weeks observation, while by adding organic waste was 410-728 ml every two weeks observation.

The concentration of organic waste would affect the amount of biogas produced. In this study, the best ratio was obtained at concentration of organic waste and wastewater $(30: 70) \%$ with an average amount of biogas at steady state was $728 \mathrm{ml}$ every two weeks observation. For the treatment with addition of organic waste as much as $40 \%$ showed a condition that did not stable after the $12^{\text {th }}$ week. This required the addition of a longer residence time.

The observations of reactor conditions was necessary to look at the performance of anaerobic reactors. One of them was the $\mathrm{pH}$ value at $40 \%$ concentration of organic waste that was acidic namely 4.91 at the end of the observation. This indicated that the anaerobic process was not running normally. Likewise with the other parameters, namely COD, BOD-5, and the total solid, where the normal treatment will occured degradation of organic substances were characterized by decreasing levels of these parameters during the fermentation process.

\section{REFERENCES}

Angelidaki, I., \& Ellegaard, L. 2003. Codigestion of manure and organic wastes in centralized biogas plants. Applied Biochemistry and Biotechnology, 109, 95-105.

Arthur, R., Baidoo, M. F., \& Antwi, E. 2011. Biogas as a potential renewable energy source: A Ghanain case study. Renewable Energy, 36(5), 1510-1516.
Bahrin, D., Destilia A., \& Pertiwi, M. B. 2011. Pengaruh jenis sampah, komposisi masukan dan waktu tinggal terhadap komposisi biogas dari sampah organik pasar di Kota Palembang. Prosiding Seminar Nasional A VoER ke-3.

Budiyono, I. N., Widiasa, S., Johari, \& Sunarso. 2010. The influence of total solid contents on biogas yield from cattle manure using rumen fluid inoculum. Energy Research Journal, 1 (1):6-11, 2010.

Creamer, K. S., Chen, Y., Williams, C. M., \& Cheng, J. J. 2010. Stable thermophilic anaerobic digestion of dissolved air flotation (DAF) sludge by cofermentation with swine manure. Bioresource Technology, 101, 3020-3024.

Dhadse, S., Kankal, N. C., \& Kumari, B. 2010. Study of diverse methanogenic and non-methanogenic bacteria used for the enhancement of biogas production. International Journal of Life Sciences Biotechnology and Pharma Research, Vol. 1, No. 2, 175192.

Fernandez, J., Perez, M., Romero, L.I. 2008. Effect of substrate concentration on dry mesophilic anaerobic digestion of organic fraction of municipal solid waste (OFMSW). Bioresource Technology. 99, 6075-6080.

Gamayanti, K. N., Pratiwiningrum, A., \& Yusiati, L. M. 2012. Pengaruh penggunaan limbah cairan rumen dan lumpur gambut sebagai starter dalam proses fermentasi metanogenik. Buletin Peternakan, Volume 36, 3239.

Ge, H.Q., Jensen, P.D., \& Batstone, D.J. 2010. Pre-treatment mechanisms during thermophilic-mesophilic temperature phased anaerobic digestion of primary sludge. Water Research, 44 (1), 123-130.

Han, S., \& Shin, H.S. 2004. Biohydrogen production by anaerobic fermentation 
of food waste. International Journal of Hydrogen Energy, 29 (6), 569-577.

Heo, N., Park, S., Lee, J., Kang, H., \& Park, D. 2003. Single-stage anaerobic codigestion for mixture wastes of simulated Korean food waste and waste activated sludge. Applied Biochemistry and Biotechnology, 107, 567-579.

Kelley, T. R., \& Walker, P. M. 2000. Bacterial concentration reduction in swine waste amended livestock feed using a single-screw dry-extrusion process. Bioresource Technology, 75 (3), 189-195.

Kim, H. W., Shin, H. S., Han, S. K., \& Oh, S. E. 2007. Response surface optimization of substrates for thermophilic anaerobic codigestion of sewage sludge and food waste. Journal of the Air and Waste Management Association, 57 (3), 309-318.

Lv, W., Schanbacher, F. L., \& Yu, Z. 2010. Putting microbes to work in sequence: recent advances in temperaturephased anaerobic digestion processes. Bioresource Technology, 101 (24), 9409-9414.

Martin-Gonzalez, L., Colturato, L.F., Font, X., Vicent, T. 2010. Anaerobic codigestion of the organic fraction of municipal solid waste with FOG waste from a sewage treatment plant: recovering a wasted methane potential and enhancing the biogas yield. Waste Management. 30, 1854-1859.

Nayono, S.E., Gallert, C., \& Winter, J. 2009. Foodwaste as a co-substrate in a fedbatch anaerobic biowaste digester for constant biogas supply. Water Science and Technology, 59 (6), 1169-1178.

Oh, G., Zhang, L., \& Jahng, D. 2008. Osmoprotectants enhance methane production from the anaerobic digestion of food wastes containing a high content of salt. Journal of
Chemical Technology and Biotechnology, 83 (9), 1204-1210.

Raheman, H., \& Mondal, S. 2012. Biogas production potential of jatropha seed cake. Biomass and Bioenergy, 37, 2530.

Scholz, V., \& Ellner, J. 2011. Use of biogas in fuel cells-current R\&D. Jurnal of Sustainable Energy \& Enviroment, Special Issue, 11-15.

Sofyan, Rahman, E. D., \& Praputri, E. 2012. Pengaruh perbandingan sampah organik dan limbah cair industri tahu pada produksi biogas. Proceeding Seminar Nasional Rekayasa Sains dan Teknologi ke-2.

Vindis, P., Mursec, B., Janzekovic, M., \& Cus, F. 2009. The impact of mesophilic and thermophilic anaerobic digestion on biogas production. Journal of Achievements in Materials and Manufacturing Engineering, 36(2), 192-198.

Wang, J., Zhang, H., Stabnikova, O., Ang, S., \& Tay, J. 2005. A hybrid anaerobic solid-system for food waste digestion. Water Science Technology, 52, 223-228.

Ward, A.J., Hobbs, P.J., Holliman, P.J., Jones, D.L. 2008. Optimization of the anaerobic digestion of agricultural resources. Bioresource Technology. 99, 7928-7940.

Wikan, W. T., Asari, A., Ana, N., \& Elita, R. 2009. Design and development of biogas reactor for farmer group Scale. Indonesian Journal of Agricultural IV, 121-128.

Zhang, Z. L., Zhang, L., Zhou, Y. L., Chen, J. C., Liang, Y. M., \& Wei, L. 2013. Pilotscale operation of enhanced anaerobic digestion of nutrientdeficient municipal sludge by ultrasonic pretreatment and codigestion of kitchen garbage. Journal of Environmental Chemical Engineering, 1, 73-78. 